\title{
Economic Growth and Financial Development Nexus in Malaysia: Dynamic Simultaneous Equations Models
}

\author{
Mohamed Ibrahim Mugableh (Corresponding author) \\ Head of Financial \&Banking Sciences Department \\ College of Administrative \&Financial Sciences \\ Irbid National University, P.O Box: 2600-Zip Code: 21110, Jordan
}

Tel: 96-27-9095-6497_E-mail:mugableh83@yahoo.com or mugableh83@gmail.com

\author{
Mohammad Salem Oudat \\ Applied Science University, Financial \&Banking Sciences Department, Bahrain \\ E-mail: mohammad.oudat@yahoo.com
}

Received: Feb. 28, $2018 \quad$ Accepted: April 11, $2018 \quad$ Published: June 1, 2018

doi:10.5296/ajfa.v10i1.12736 URL: https://doi.org/10.5296/ajfa.v10i1.12736

\begin{abstract}
This paper estimates the equilibrium and causality relationships among gross domestic product, energy consumption, financial development, foreign direct investment inflows, and gross fixed capital formation. Different econometrics tests like descriptive statistics, ARCH, KPSS unit root, Johansen and Juselius's co-integration, VECM Granger causality, and ARDL equilibrium relationships have been employed in Malaysia over the (1971-2013) period. The correlation matrix results indicate a linear association among variables. The null hypotheses of Heteroscedasticity and non-stationary have been rejected implying the appropriate use of VECM and ARDL approach. The VECM Granger causality findings show a long-run bidirectional among the variables. The ARDL approach results demonstrate that energy consumption, financial development, foreign direct investment inflows, and gross fixed capital formation augment gross domestic product in long-run. However, the findings of this paper add essential implications to policy makers and scholars in fields of economic, energy, and finance.
\end{abstract}

Keywords: ARCH; ARDL, Economic Growth, VECM; Malaysia. 


\section{Introduction}

Over the past era, several studies have been conducted to debate the relationships between gross domestic product (GDP) and its determinants. That is, numerous papers have debated the relationship between GDP and energy consumption (EC) (See Alamet al.,2012; Alamet al.,2011; Altinay \& Karagol, 2004; Apergis \& Payne, 2010; Asafu-Adjaye, 2000; Belloumi, 2009; Dagher \& Yacoubian, 2012; Jobert \& Karanfil, 2007; Lean \& Smith, 2010; Menyah \& Wolde-Rufael, 2010; Ozturk \& Acaravci, 2010; Wanget al.,2011; Zhang \&Cheng, 2009). The relationship between GDP and financial development (FD) has been discussed by several studies (See Abu-Bader \&Abu-Qarn, 2008; Al-Yousif, 2002; Bojanic, 2012; Calderon\&Liu, 2003; Camposet al.,2012; Chang, 2002; Christopoulos \& Tsionas, 2003; Deb \& Mukherjee, 2008; Hassanet al.,2011; Hondroyianniset al.,2005; Hsuehet al.,2013; Karet al.,2011; Lee \&Chang, 2009; Liang \& Teng, 2006; Shan \& Jianhong, 2006; Yang \& Yi, 2008; Zhang et al.,2012). In addition, the relationship between GDP and foreign direct investment inflows (FDI) has been argued by studies of Boutabba (2014) and Hamdiet al.(2014).

With regard to the research on the determinants of GDP in Malaysia, a bulk of studies have been conducted in such area (e.g., Ang, 2008a; Ang, 2008b; Ang \& Mckibbin, 2007; Anwar \&Sun, 2011; Azlina \& Mustapha, 2012; Bekhet \& Othman, 2018; Bekhet \& Yasmin, 2013; Bekhet \& Othman, 2011; Islamet al.,2013; Shahbazet al.,2013). Thus, the main purpose of the current article is to supplement the existing studies on the determinants of GDP by bringing a new evidence for the case of a developed country in South East Asia (i.e., Malaysia). Unlike the previous studies for Malaysia, this study employs the autoregressive conditional Heteroscedasticity (ARCH) test proposed by Engle (1982) to either accept or reject the null hypothesis of Heteroscedasticity. If this hypothesis is rejected, then the error terms are homoscedastic and the vector error correction model (VECM) would be employed to examine the causality directions in long-run and short-run. In addition, it analyses the equilibrium relationships between GDP and its determinants by employing the econometrics approach (i.e., the autoregressive distributed lag (ARDL) approach).

\section{Snapshot ofthe Malaysian economy}

Over the past two decades, the Malaysian government has conducted the national vision policy and economic transformation policy. These policies have been concentrated on stimulating economic growth and achieving the 2020 vision. That is, the main objectives of these policies are to (1) focus on the high value added activities and total factor productivity in economic sectors (i.e., manufacturing, services, and agricultural). (2) Emphasize on the collaboration between private and public sectors through establishing small and medium projects. (3) Concentrate on the research activities, development activities, and human capital development. (4) Improve the sustainability of energy supply and reduce the dependence on petroleum products through encouraging the use of biofuel, biodiesel, and solar energy (United Nations Development Programme Report, 2006). The objectives of these policies however, have improved the GDP, EC, FD, and FDI growth rates. Fig. 1 shows that the GDP achieved an annual growth rate of $6 \%$ for the (1971-2013) period. 


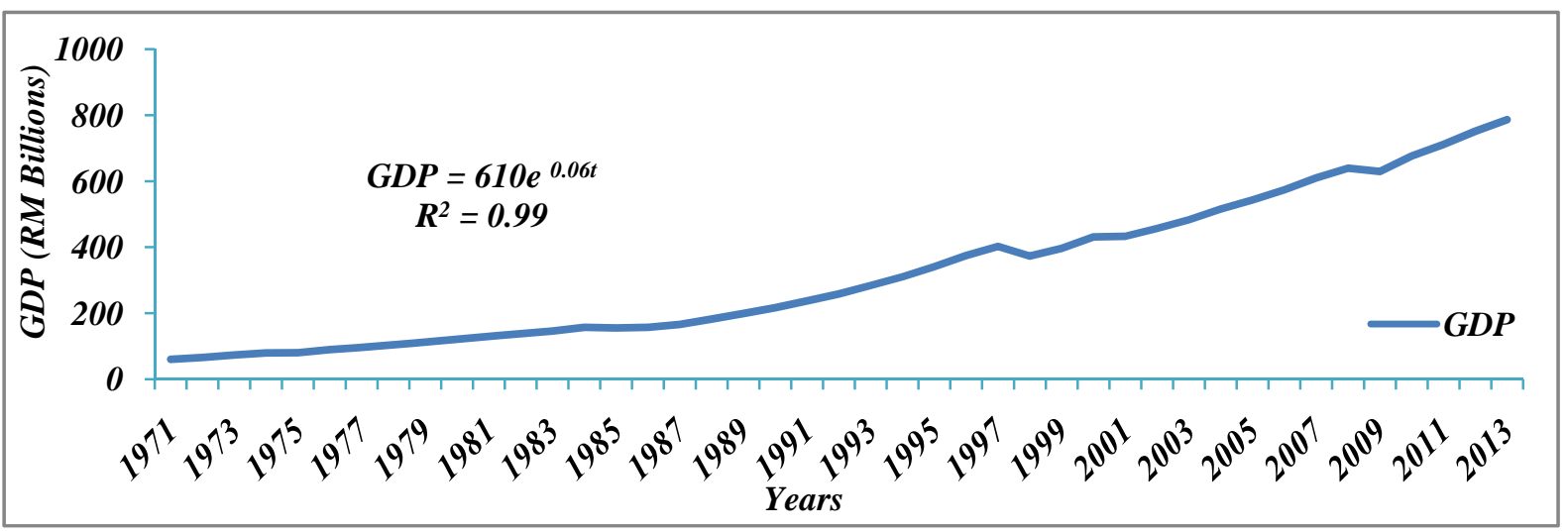

Figure 1. The growth rate of Gross Domestic Product $(2010=100)$ in Malaysia for the (1971-2013) period

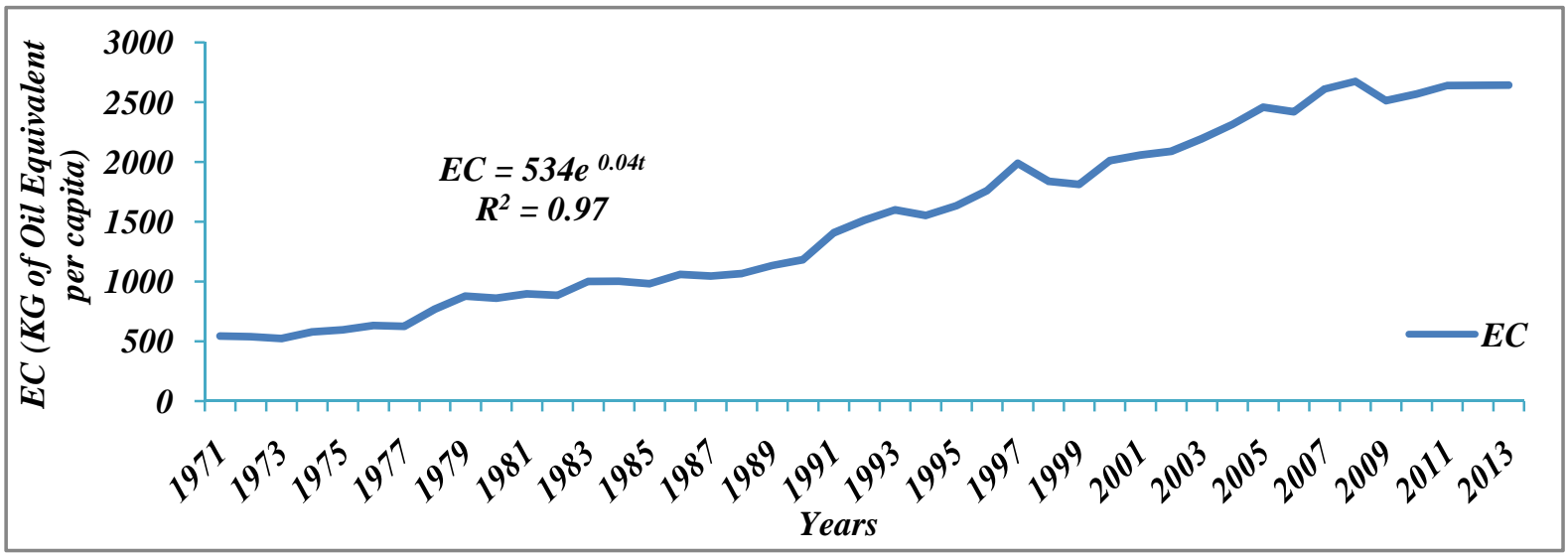

Figure 2. The growth rate of Energy Consumption in Malaysia for the (1971-2013) period Fig. 2 demonstrates that the EC registered an annual growth rate of 4\% for the (1971-2013) period. Fig. 3 shows that FD registers an annual growth rate of 3\% for the (1971-2013) period. 


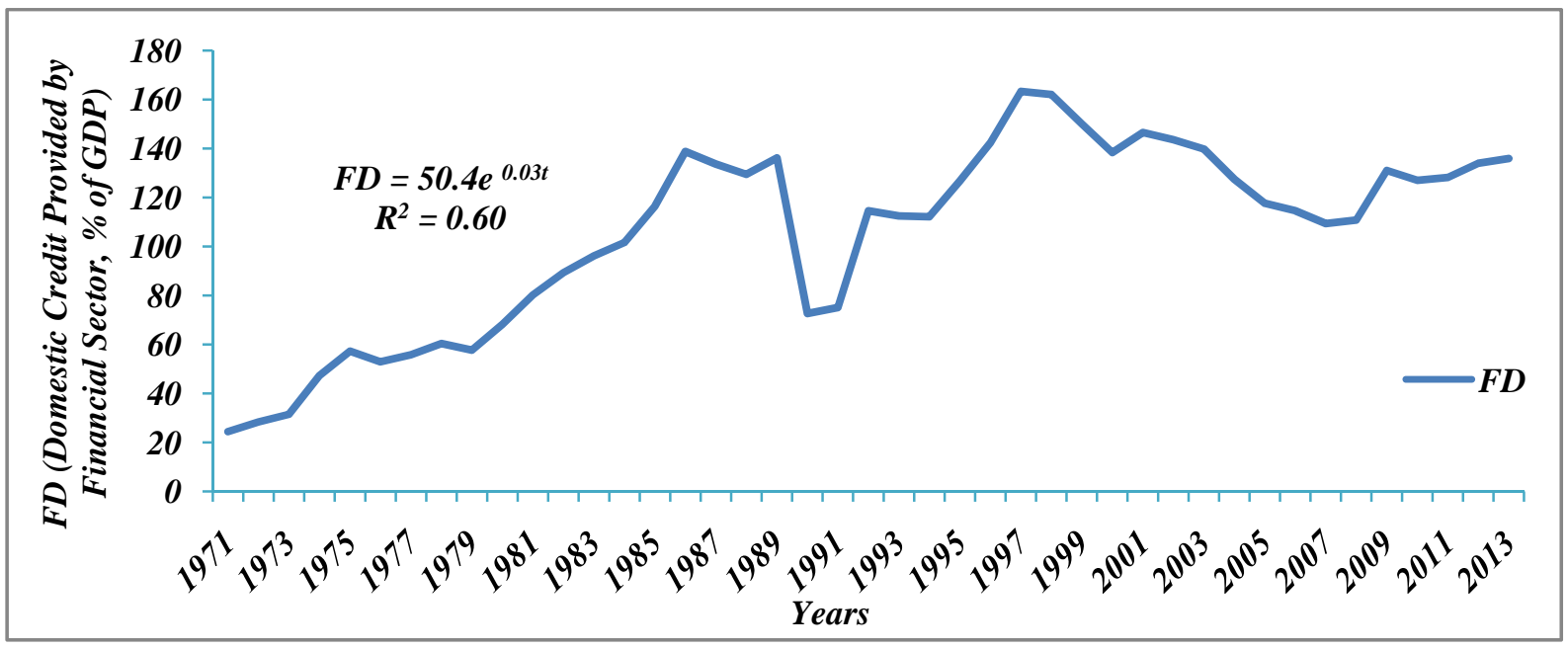

Figure 3. The growth rate of Financial Development in Malaysia for the (1971-2013) period

Fig. 4 also demonstrates that FDI inflows achieved an annual growth rate of $9 \%$ for the (1971-2013) period.

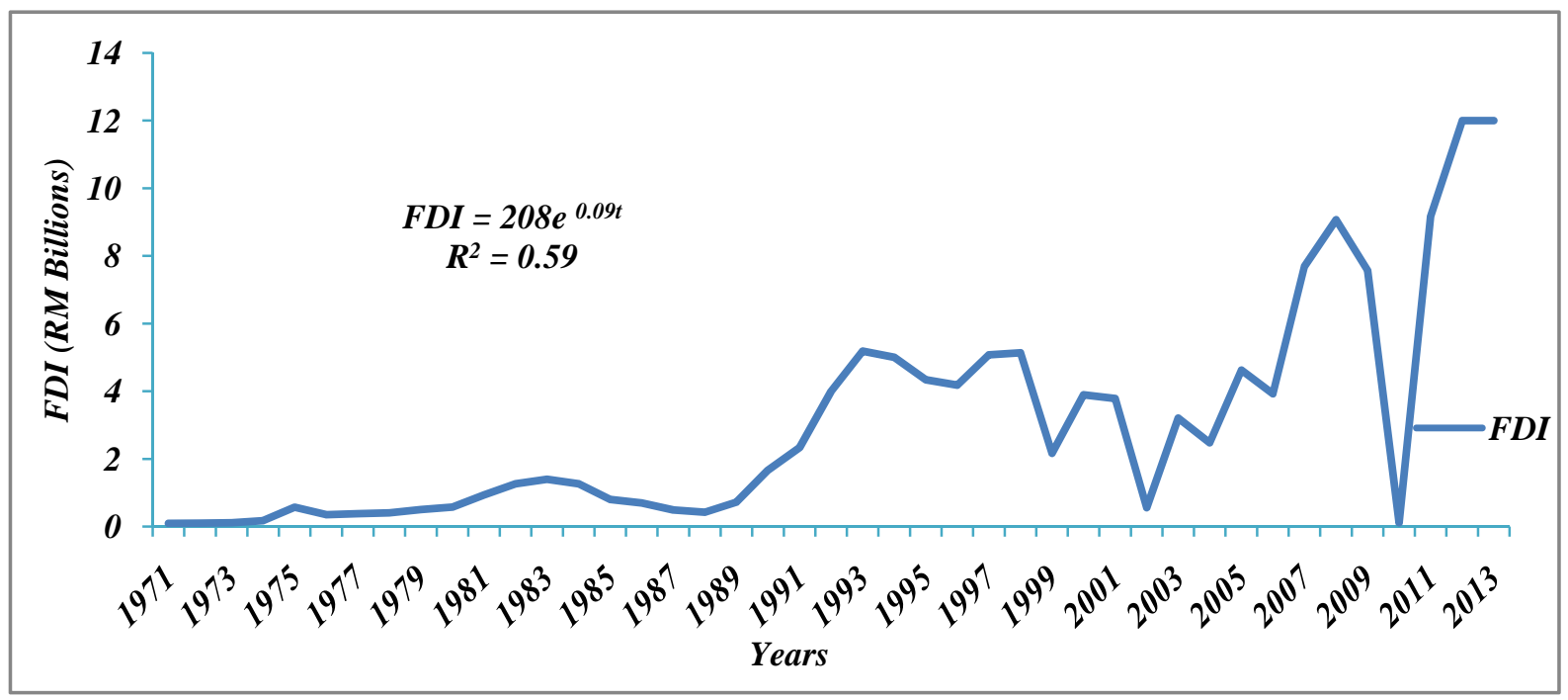

Figure 4. The growth rate of Foreign Direct Investment flows into Malaysia for the (1971-2013) period

\section{Review of literature}

The current paper has classified the review of literature into three groups. The first group deliberates the relationship between GDP and EC. The second group discusses the relationship between GDP and FD. The third group demonstrates the relationship between GDP and FDI.

\subsection{GDP and EC}

The literature includes two perspectives for the relationships between GDP and EC. The first perspective is the neutrality hypothesis which states that a country might follow an energy 
conservation policy that impedes GDP. For example, Alamet al. (2011) found no causal relationship between EC and GDP for India. Altinay and Karagol (2004), Jobert and Karanfil (2007), and Ozturk and Acaravci (2010) found similar results for Turkey, while Zhang and Cheng (2009) found them for China. The second perspective is the non-neutrality hypothesis which implies that a country's GDP is highly dependent on EC, one of the main thrusts for achieving higher GDP. Alamet al. (2012) found long-run bidirectional causality between electricity consumption (ELC) and GDP for Bangladesh. Apergis and Payne (2010) established bidirectional causality between EC and GDP in 20 OECD countries. Asafu-Adjaye (2000) showed bidirectional causality between EC and GDP for Thailand and the Philippines; similar results were found by Belloumi (2009) for Tunisia, Dagher and Yacoubian (2012) for Lebanon and Wang et al. (2011) for China. Lean and Smith (2010) pointed to unidirectional Granger causality running from ELC to GDP in the long-run for five ASEAN countries. Menyah and Wolde-Rufael (2010) established unidirectional causality running from EC to GDP for South Korea.

\subsection{GDP and FD}

Recently, a pool of proof in the literature has argued that FD is an important driver of GDP. Patrick (1966) argued that the relationship between FD and GDP is based in two hypotheses. The supply leading hypothesis in the case of FD causes GDP, while the demand following hypothesis if GDP causes FD. Bojanic (2012) investigated the long-run relationship and the causality direction between FD and GDP for Bolivia during the (1940-2010) period. The results indicated long-run relationship between FD and GDP. The findings also demonstrated the existence of supply-leading hypothesis (i.e., a unidirectional Granger causality from FD to GDP). Similar results were found by Hsuehet al. (2013) in ten Asian countries, Lee and Chang (2009) for a set of 37 countries, Liu and Hsu (2006) for three Asian countries, namely, Taiwan, Korea, and Japan, Yang and Yi (2008) for Korea, and Zhang et al. (2012) for 286 Chinese cities over the (2001-2006) period. On the other hand, Liang and Teng (2006) examined the direction of causality between GDP and FD for the case of China over the (1952-2001) period. They employed the vector autoregressive (VAR) model and found a unidirectional causality running from GDP to FD. Specifically, the results confirmed the existence of the demand following hypothesis. However, the bidirectional causality between FD and GDP was established by several studies (e.g., Abu-Bader \& Abu-Qarn, 2008; Al-Yousif, 2002; Calderon \& Liu, 2003; Deb \&Mukherjee, 2008; Hassan et al., 2011). The no clear consensus on the direction of causality between FD and GDP was found by Chang (2002) in China, and Karet al. (2011) in Middle East and North Africa countries for the (1980-2007) period.

\subsection{GDP and FDI Inflows}

The relationship between FDI inflows and GDP has been debated by diverse studies. Ang (2008a) utilized the ARDL approach to examine the relationship between FDI inflows and GDP for the case of Malaysia. The results indicated that FDIinflows stimulated GDP via promoting foreign investments. Ang and Mckibbin (2007) investigated whether FDIinflows increased GDP using annual time-series data for the (1960-2001) period. They employed 
co-integration and causality tests and found that FDI stimulated GDP in Malaysia. Anwar and Sun (2011) examined the relationship between FDI inflows and GDP, based on annual time-series data for the (1970-2007) period. The findings revealed that the growth of FDI in Malaysia enthused GDP. Hamdiet al. (2014) analysed the determinants of GDP using quarterly time-series data for the (1980-2010) period. The results indicated bidirectional causality between FDI inflows and GDP in Bahrain.

\section{Model construction and data}

The current paper analyses equilibrium and causality relationships among GDP, EC, FD, FDI inflows, and gross fixed capital formation (K, \% of GDP) in Malaysia over the (1971-2013) period. Eq. (1) assumes that these variables determine the GDP.

$$
\mathrm{LnGDP}_{\mathrm{t}}=\gamma_{0}+\gamma_{1} \mathrm{LnEC}_{\mathrm{t}}+\gamma_{2} \mathrm{LnFD}_{\mathrm{t}}+\gamma_{3} \mathrm{LnFDI}_{\mathrm{t}}+\gamma_{4} \mathrm{LnK}_{\mathrm{t}}+\varepsilon_{\mathrm{t}}
$$

Where, $\gamma_{0}$ denotes the intercept term; $\gamma_{\mathrm{i}} \mathrm{s}[\mathrm{i}=1 \ldots 4]$ stand for the slope parameters; and $\varepsilon_{\mathrm{t}}$ denotes the error term. All the variables used in this paper were transformed into natural logarithmic forms (Ln)s. The transformation into natural logarithmic form was used to stabilize the variance $\left(\sigma^{2}\right)$ of secondary time-series data. The secondary time-series variables have been collected from the World Bank, Development Indicators Databases, 2017, (http://data.worldbank.org/country/malaysia).

\section{Econometrics Methodology}

Methodologically speaking, the regression results are likely to be spurious if the variables are non-stationary. The solution to the spurious phenomenon is to differentiate variables and to use co-integration mechanism. Nowadays, there are three models for implementing the co-integration mechanism: Engle and Granger's (1987) two-step process, henceforth referred to as the VAR model; Johansen and Juselius's (1990) trace and maximal eigenvalues statistics tests, hereafter referred to as the VECM; and Pesaran, Shin, and Smith's (2001) bounds F-statistics, henceforth referred to as the ARDL approach.

The VAR model in Eq. (2) is conducted under the condition that variables are not co-integrated.

$$
\mathrm{z}_{\mathrm{t}}=\alpha+\mathrm{X}_{1} \mathrm{z}_{\mathrm{t}-1}+\ldots+\mathrm{X}_{\mathrm{i}} \mathrm{z}_{\mathrm{t}-\mathrm{h}}+\varepsilon_{\mathrm{t}}, \quad \mathrm{X}_{\mathrm{i}}(\mathrm{i}=1, \ldots 5)
$$

Where, $z_{t}$ is the $5 \times 1$ vector of selected variables (i.e., $\operatorname{LnGDP}_{t}, \mathrm{LnEC}_{t}, \mathrm{LnFD}_{t}, \mathrm{LnFDI}_{t}$, and $\left.\mathrm{LnK}_{\mathrm{t}}\right)^{\prime}$. The series $\mathrm{Z}_{\mathrm{t}}$ is stationary at level (i.e., $I(0)$ ) and is said to be co-integrated if the series $\varepsilon_{t}$ is stationary at $I(0) . \alpha$ and $\varepsilon_{t}$ are the $5 \times 1$ vector of intercepts and error terms, respectively. The $\mathrm{X}_{\mathrm{i}}$ is a $5 \times 5$ matrix of parameters at the lag length (h). The $\mathrm{h}$ is obtained by using the Ackaike information criterion (AIC). Hamdiet al. (2014) argued that the AIC is superior and improves performance over the Schwartz information and Hannan-Quinn information criteria in a small sample size. The VECM is applied if the $\left(\varepsilon_{t}\right) \sin$ Eq. (2) is homoscedastic using the ARCH test under the assumption that the series $z_{t}$ is stationary at the first differences (i.e., I(1)). Thus, Eq. (2) can be turned as in Eq. (3).

$$
\Delta \mathrm{z}_{\mathrm{t}}=\Pi \mathrm{z}_{\mathrm{t}}+\mathrm{X}_{1} \Delta \mathrm{z}_{\mathrm{t}-1}+\mathrm{X}_{2} \Delta \mathrm{z}_{\mathrm{t}-2}+\ldots \ldots+\mathrm{X}_{\mathrm{i}} \Delta \mathrm{z}_{\mathrm{t}-\mathrm{h}}+\varepsilon_{\mathrm{t}}, \quad \mathrm{X}_{\mathrm{i}}(\mathrm{i}=1, \ldots 5)
$$




\section{Macrothink}

Where, $\Delta$ denotes the first difference operator; $\prod z_{t}$ denotes the full rank that is used to test the null hypothesis $\left(H_{0}\right)$ of no co-integration among variables.

$$
\left[\begin{array}{l}
\Delta \mathrm{LnGDP}_{\mathrm{t}} \\
\Delta \mathrm{LnEC}_{\mathrm{t}} \\
\Delta \mathrm{LnFD}_{\mathrm{t}} \\
\Delta \mathrm{LnFDI}_{\mathrm{t}} \\
\Delta \mathrm{LnK}_{\mathrm{t}}
\end{array}\right]=\left[\begin{array}{l}
\alpha_{1 \mathrm{t}} \\
\alpha_{2 \mathrm{t}} \\
\alpha_{3 \mathrm{t}} \\
\alpha_{4 \mathrm{t}} \\
\alpha_{5 \mathrm{t}}
\end{array}\right]+\sum_{\mathrm{s}=0}^{\mathrm{h}=0}\left[\begin{array}{l}
\beta_{11 \mathrm{~s}} \beta_{12 \mathrm{~s}} \beta_{13 \mathrm{~s}} \\
\beta_{21 \mathrm{~s}} \beta_{22 \mathrm{~s}} \beta_{23 \mathrm{~s}} \\
\beta_{31 \mathrm{~s}} \beta_{32 \mathrm{~s}} \beta_{33 \mathrm{~s}} \\
\beta_{41 \mathrm{~s}} \beta_{42 \mathrm{~s}} \beta_{43 \mathrm{~s}} \\
\beta_{51 \mathrm{~s}} \beta_{52 \mathrm{~s}} \beta_{53 \mathrm{~s}}
\end{array}\right] \ldots . . .\left[\begin{array}{l}
\beta_{14 \mathrm{~s}} \beta_{15 \mathrm{~s}} \\
\beta_{24 \mathrm{~s}} \beta_{25 \mathrm{~s}} \\
\beta_{34 \mathrm{~s}} \beta_{35 \mathrm{~s}} \\
\beta_{44 \mathrm{~s}} \beta_{45 \mathrm{~s}} \\
\beta_{54 \mathrm{~s}} \beta_{55 \mathrm{~s}}
\end{array}\right]\left[\begin{array}{l}
\Delta \mathrm{LnGDP} \\
\Delta \mathrm{LnEC} \\
\Delta \mathrm{LnFD} \\
\Delta \mathrm{LnFDI} \\
\Delta \mathrm{LnK}
\end{array}\right]+\left[\begin{array}{l}
\zeta_{\mathrm{tt}} \\
\zeta_{2 \mathrm{t}} \\
\zeta_{3 \mathrm{t}} \\
\zeta_{4 \mathrm{t}} \\
\zeta_{5 \mathrm{t}}
\end{array}\right]\left[\begin{array}{l}
\mathrm{EET} \\
\mathrm{EET} \\
\mathrm{EET} \\
\mathrm{EET} \\
\mathrm{EET}
\end{array}\right]_{\mathrm{t}-1}\left[\begin{array}{l}
\varepsilon_{1 \mathrm{t}} \\
\varepsilon_{2 \mathrm{t}} \\
\varepsilon_{3 \mathrm{t}} \\
\varepsilon_{4 \mathrm{t}} \\
\varepsilon_{5 \mathrm{t}}
\end{array}\right](4)
$$

Where, Eq. (4) represents the VECM; $\Delta$ is the first difference operator; $\alpha_{i t}[i=1, \ldots 5]$ represent the intercept terms; $\beta_{\mathrm{ij}}[\mathrm{i}, \mathrm{j}=1, \ldots ., 5]$ denote the F-statistics coefficients to evaluate the causality directions in the short-run; $\zeta_{\mathrm{it}}[\mathrm{i}=1, \ldots 5]$ signify the t-statistics coefficients of equilibrium error terms $\left(\mathrm{EET}_{\mathrm{t}-1}\right) \mathrm{s}$ that are used to evaluate the bidirectional causality in long-run; and $\varepsilon_{\mathrm{it}}[\mathrm{i}=1, \ldots .5]$ are the disturbance terms.

The ARDL approach has been employed in this paper to analyselong-run and short-run relationships among variables. Bekhet and Mugableh (2012), Bekhet and Mugableh (2013), Bekhet and Mugableh (2016), Mugableh (2013, 2015a, 2015b, 2015c, 2017a, 2017b) and Narayan (2005) argued that this approach has statistical and econometrics advantages. (1) The ARDL approach can be utilized in a small sample size (i.e., less than 80 observations). (2) It can envelop the variables at I(0), I(1), and both. Eq. (5) explains the coefficients of long-run and short-run relationships through the ARDL approach.

$$
\begin{aligned}
\Delta \operatorname{LnGDP}_{\mathrm{t}}= & \alpha_{0}+\alpha_{1 \mathrm{t}} \operatorname{LnGDP}_{\mathrm{t}-1}+\alpha_{2 \mathrm{t}} \mathrm{LnEC}_{\mathrm{t}-1}+\alpha_{3 \mathrm{t}} \mathrm{LnFD}_{\mathrm{t}-1}+\alpha_{4 \mathrm{t}} \mathrm{LnFDI}_{\mathrm{t}-1}+\alpha_{5 \mathrm{t}} \mathrm{LnK}_{\mathrm{t}-1} \\
& +\sum_{\mathrm{s}=1}^{\mathrm{h}} \alpha_{6 \mathrm{~s}} \Delta \operatorname{LnGDP}_{\mathrm{t}-\mathrm{s}}+\sum_{\mathrm{s}=0}^{\mathrm{h}} \alpha_{7 \mathrm{~s}} \Delta \operatorname{LnEC}_{\mathrm{t}-\mathrm{s}}+\sum_{\mathrm{s}=0}^{\mathrm{h}} \alpha_{8 \mathrm{~s}} \Delta \mathrm{LnFD}_{\mathrm{t}-\mathrm{s}} \\
& +\sum_{\mathrm{s}=0}^{\mathrm{h}} \alpha_{9 \mathrm{~s}} \Delta \operatorname{LnFDI}_{\mathrm{t}-\mathrm{s}}+\sum_{\mathrm{s}=0}^{\mathrm{h}} \alpha_{10 \mathrm{~s}} \Delta \mathrm{LnK}_{\mathrm{t}-\mathrm{s}}+\varepsilon_{\mathrm{t}}
\end{aligned}
$$

Here, $\Delta$ represents the first difference operator; $\alpha_{0}$ denotes the intercept term; $\alpha_{i t}[i=1, \ldots .5]$ represent the long-run coefficients that are used to test long-run relationships; $\alpha_{\text {is }}[i=6, \ldots .10]$ denote the short-run coefficients to estimate short-run relationships; $h$ signifies the lag length that obtained by the AIC; and $\varepsilon_{\mathrm{t}}$ is the error term.

\section{Results analyses and discussions}

\subsection{Descriptive statistics test}

Table 1 provides the findings of descriptive statistics tests. The correlation matrix results show that the variables are departed from dependence (i.e., linearly correlated). 
Table 1. Descriptive statistics test results.

\begin{tabular}{llllll}
\hline & LnGDP $_{\mathrm{t}}$ & LnEC $_{\mathrm{t}}$ & LnFD $_{\mathrm{t}}$ & LnFDI $_{\mathrm{t}}$ & LnK $_{\mathrm{t}}$ \\
\hline Mean & 3.0911 & 33084.9 & 104.93 & 3.8005 & 27.825 \\
Median & 2.4811 & 27711.2 & 114.59 & 3.6253 & 25.318 \\
Maximum & 7.5111 & 75907.3 & 163.35 & 8.7628 & 43.586 \\
Minimum & 6.0411 & 6092.98 & 24.449 & 0.0567 & 20.570 \\
Stand. Dev. & 2.0911 & 23489.7 & 38.348 & 1.8407 & 6.8389 \\
Skewness & 0.5726 & 0.52615 & -0.569 & 0.5608 & 1.0085 \\
Kurtosis & 2.0480 & 1.87294 & 2.1903 & 3.5022 & 2.7362 \\
Jarque-Berra & 3.8807 & 4.16080 & 3.4159 & 2.6426 & 5.2419 \\
Probability & 0.1437 & 0.12488 & 0.1812 & 0.2668 & 0.1068 \\
LnGDP & 1.00 & & & & \\
LnEC $_{\mathrm{t}}$ & 0.89 & 1.00 & & & \\
LnFD $_{\mathrm{t}}$ & 0.55 & 0.71 & 1.00 & & \\
LnFDI $_{\mathrm{t}}$ & 0.02 & 0.07 & -0.01 & 1.00 & \\
LnK $_{\mathrm{t}}$ & -0.14 & -0.05 & 0.17 & 0.67 & \\
$\mathrm{R}^{2}$ & 0.87 & & & & \\
D-W & 1.68 & & & & \\
\hline
\end{tabular}

Source: The output of E-views econometric software package (version 8.1).

Table 1 also shows that the $H_{0}$ of non-normality has been rejected as the probability values of Jarque-Berra statistics test are greater than $10 \%$. There is no evidence of spurious regression because the joint coefficient of determination $\left(\mathrm{R}^{2}\right)$ equals 0.87 and less than 1.68 (i.e., the Durbin-Watson statistics ( $\mathrm{D}-\mathrm{W})$ value). Thus, these results lead us to further examining the equilibrium and causality relationships between GDP and its determinants.

\subsection{ARCH test}

Table 2 demonstrates that the $H_{0}$ of Heteroscedastic co-integrating relationship for the $\left(\varepsilon_{\mathrm{t}}\right) \sin$ Eq. (3) is rejected. The F-statistics probability value (i.e., 0.14) and the chi-square $\left(\chi^{2}\right)$ probability value (i.e., 0.12) are greater than 10\%. Brooks (2008) argued that if F-statistics and the $\chi^{2}$ probabilities values are greater than $10 \%$, the $H_{0}$ of the Heteroscedastic co-integrating relationship would be rejected.

Table 2. ARCH test results.

\begin{tabular}{lll}
\hline & Computed value & Probability value \\
\hline F-statistics (q, 35) & 1.96 & 0.14 \\
$\mathrm{~T} \times \mathrm{R}^{2}\left(\chi^{2}(\mathrm{q})\right)$ & 36.5 & 0.12 \\
\hline
\end{tabular}

Notes: (1) T is the number of observations.

(2) q denotes the degree of freedom which equal the number of $(\mathrm{h}=3)$ that obtained using AIC.

Source: The output of E-views econometric software package (version 8.1). 
In other words, there is a homoscedastic co-integrating relationship and the VECM would be employed to examine the causality directions in long-run and short-run. Before using VECM and ARDL approach we have to confirm that the variables are stationary at I(1) using Kwiatkowski, Phillips, Schmidt, and Shin, KPSS (1992) test

\subsection{Stationary test}

The third step in this paper is to determine the integration level of variables. The stationary testing is mandatory to detect the stability of time-series data. Harris (1995) argued that the non-stationary variables are contained random and deterministic time trends. In other words, the appropriate procedure is to differentiate time-series variables in order to remove these trends. However, the KPSS test has been employed to decide the integration levels of variables. The results in Table 3 show that the variables are stationary at $I(1)$.

Table 3. KPSS test results

\begin{tabular}{lll}
\hline Variables & KPSS LM computed test statistics values & Decision \\
\hline LnGDP $_{t}$ & $0.35^{*}$ & Stationary at $I(1)$ \\
nnEC $_{t}$ & $0.36^{*}$ & Stationary at $I(1)$ \\
LnFD $_{t}$ & $0.23^{*}$ & Stationary at $I(1)$ \\
nnFDI $_{t}$ & $0.13^{* *}$ & Stationary at $I(1)$ \\
nnK $_{t}$ & $0.26^{*}$ & Stationary at $I(1)$ \\
\hline
\end{tabular}

Notes:(1)The KPSS LM computed test statistics values are compared with the asymptotic critical values (i.e., $1 \%=0.22,5 \%=0.15$, and $10 \%=0.12$ ).

(2) ${ }^{* * *}$ represent the significance at $1 \%$ and $10 \%$ levels, respectively.

(3) The analysis was conducted using intercept and time-trend.

Source: The output of E-views econometric software package (version 8.1).

Thus, the VECM is employed to evaluate the causality directions in long-run and short-run. Also, the ARDL approach is utilized to examine long-run and short-run relationships.

\subsection{Co-integration test}

The fourth step is principally important to either accept or reject the $H_{0}$ of no co-integration. However, the results in last subsection confirm that the variables are stationary at $I(1)$, then the full rank (i.e., $\prod z_{t}$, Eq. (3)) is employed to test co-integration among variables. In fact, the $\Pi$ represents the number of eigenvalues in the trace statistics test ( $\lambda$ trace) and maximal statistics test $(\lambda \max )$. Table 4 demonstrates the existence of two co-integrating vectors among variables. These results are in line with the results obtained for Bahrain using bounds F-statistics test (Hamdiet al., 2014). 
Table 4. Co-integration test results for the $\mathrm{LnGDP}_{\mathrm{t}}$ function.

\begin{tabular}{lllll}
\hline No. of C.V & $\lambda$ trace & $5 \%$ critical values & $\lambda \max$ & $5 \%$ critical values \\
\hline $\mathrm{r}=1 \rightarrow$ & $96.5^{*} \rightarrow$ & 69.8 & $44.9^{*} \rightarrow$ & 33.9 \\
$\mathrm{r}=2 \rightarrow$ & $51.6^{*} \rightarrow$ & 47.9 & $29.8^{*} \rightarrow$ & 27.6 \\
$\mathrm{r}=3$ & 21.8 & 29.8 & 16.8 & 21.1 \\
$\mathrm{r}=4$ & 5.00 & 15.5 & 4.97 & 14.3 \\
$\mathrm{r}=5$ & 0.03 & 3.84 & 0.03 & 3.84 \\
\hline
\end{tabular}

Notes:

(1)r is the number of co-integrating vectors (C.V).

(2) ${ }^{*}$ represents the existence of co-integrating relationships at the $5 \%$ significance level.

(3) The 5\% critical values were obtained from Mackinnon et al.(1999, p. 570).

Source: The output of E-views econometric software package (version 8.1).

\subsection{VECM Granger causality analyses}

The results of the ARCH test confirm the existence of a homoscedastic co-integration relationship among the variables. Thus, the VECM in Eq. (4) is employed to determine the causality directions in long-run and short-run. Table 5 shows bidirectional Granger causality between variables in long-run, as the coefficients of $\left(\mathrm{EET}_{\mathrm{t}-1) \mathrm{s}}\right.$ are in negative signs and significant at the $1 \%$ and $5 \%$ levels. These results are in line with the findings obtained for India and Bahrain (see Boutabba, 2014 and Hamdiet al., 2014, respectively).

Table 5. VECM Granger causality analyses results.

\begin{tabular}{|c|c|c|c|c|c|c|}
\hline \multirow{3}{*}{ Variables } & \multicolumn{6}{|c|}{ Sources of causation } \\
\hline & Short-run & & & & & Long-run \\
\hline & $\Delta \mathrm{LnGDP}_{\mathrm{t}}$ & $\Delta \mathrm{LnEC}_{\mathrm{t}}$ & $\Delta \mathrm{LnFD}_{\mathrm{t}}$ & $\Delta$ LnFDI $_{t}$ & $\Delta \mathrm{LnK}_{\mathrm{t}}$ & \\
\hline$\Delta$ LnGDP $_{t}$ & - & $2.77(0.06)^{*}$ & $0.27(0.84)$ & $0.46(0.71)$ & $0.63(0.60)$ & $-0.2(0.03)^{* *}$ \\
\hline$\Delta \operatorname{LnEC}_{t}$ & $1.25(0.31)$ & - & $2.29(0.10)^{*}$ & $1.16(0.34)$ & $0.34(0.80)$ & $-0.6(0.00)^{* * *}$ \\
\hline$\Delta \mathrm{LnFD}_{\mathrm{t}}$ & $0.47(0.70)$ & $0.23(0.88)$ & - & $2.11(0.11)$ & $2.31(0.10)^{*}$ & $-0.7(0.00)^{* * *}$ \\
\hline$\Delta \mathrm{LnFDI}_{\mathrm{t}}$ & $1.09(0.37)$ & $1.67(0.19)$ & $0.78(0.52)$ & - & $1.66(0.20)$ & $-1.6(0.00)^{* * *}$ \\
\hline$\Delta \mathrm{LnK}_{\mathrm{t}}$ & $0.76(0.52)$ & $1.79(0.17)$ & $1.07(0.37)$ & $1.08(0.37)$ & - & $-2.7(0.01)^{* * *}$ \\
\hline
\end{tabular}

Note: ${ }^{* * *},{ }^{* *}, *$ denote the $1 \%, 5 \%$, and $10 \%$ significance levels, respectively.

Source: The output of E-views econometric software package (version 8.1).

The long-run bidirectional Granger causality between $\Delta \mathrm{LnFD}_{\mathrm{t}}$ and $\Delta \mathrm{LnGDP}_{\mathrm{t}}$ confirms the existence of supply and leading hypotheses in Malaysia. Table 5 also shows a unidirectional Granger causality running from $\Delta \mathrm{LnEC}_{\mathrm{t}}$ to $\Delta \mathrm{LnGDP}_{\mathrm{t}} ; \Delta \mathrm{LnFD}_{\mathrm{t}}$ to $\Delta \mathrm{LnEC}_{\mathrm{t}}$; and $\Delta \mathrm{LnK}_{\mathrm{t}}$ to $\Delta \mathrm{LnFD}_{\mathrm{t}}$. The unidirectional Granger causality from $\Delta \mathrm{LnEC}_{\mathrm{t}}$ to $\Delta \mathrm{LnGDP}_{\mathrm{t}}$ is similar to the finding obtained for South Korea (Menyah \& Wolde-Rufael, 2010). Therefore, the 
non-neutrality hypothesis is existed in Malaysia because the GDP is highly dependent on the EC.

\subsection{Equilibrium relationships analyses}

The ARDL approach has been implemented to estimate long-run and short-run relationships in Eq. (5). Table 6 demonstrates that $\mathrm{LnEC}_{\mathrm{t}-1}, \mathrm{LnFD}_{\mathrm{t}-1}, \mathrm{LnFDI}_{\mathrm{t}-1}$, and $\mathrm{LnK}_{\mathrm{t}-1}$ are positively associated with the $\triangle \mathrm{LnGDP}_{\mathrm{t}}$ in the long-run.A $1 \%$ increases in energy consumption and gross fixed capital formation add in economic growth by 0.98 and 14.2 , respectively.A $1 \%$ increases in financial development and foreign direct investment inflows improve economic growth by 0.27 and 0.25 , respectively. These results are confirmed by the findings obtained for Bahrain (Hamdiet al., 2014).

Table 6. Equilibrium relationships analyses results.

\begin{tabular}{|c|c|c|c|}
\hline \multicolumn{4}{|c|}{ Dependent variable $=\mathrm{LGDP}_{\mathrm{t}}$} \\
\hline Variable & $\mathrm{Co}$ & Standard error & Probability value \\
\hline \multicolumn{4}{|c|}{ Panel A: Long-run analysis results } \\
\hline Constant & & 0.50 & 0.01 \\
\hline $\operatorname{LnEC}_{\mathrm{t}-1}$ & $0.98^{*}$ & 0.05 & 0.10 \\
\hline $\operatorname{LnFD}_{\mathrm{t}-1}$ & $0.27^{*}$ & 0.14 & 0.10 \\
\hline $\operatorname{LnFDI}_{t-1}$ & $0.25^{*}$ & 0.16 & 0.10 \\
\hline $\operatorname{LnK}_{\mathrm{t}-1}$ & $14.2^{* * *}$ & 0.65 & 0.01 \\
\hline $\mathrm{R}^{2}$ & \multicolumn{2}{|c|}{0.88} & \\
\hline $\operatorname{Adj}-R^{2}$ & \multicolumn{2}{|c|}{0.85} & \\
\hline \multicolumn{4}{|c|}{ Panel B: Short-run analysis results (the lag order $=0,0,0,0,1$ based on the AIC) } \\
\hline$\Delta \mathrm{LnEC}_{\mathrm{t}}$ & & 0.07 & 0.01 \\
\hline$\Delta \mathrm{LnFD}_{\mathrm{t}}$ & $-0.05^{* *}$ & 0.02 & 0.02 \\
\hline$\Delta \mathrm{LnFDI}_{\mathrm{t}}$ & $0.01^{* *}$ & 0.01 & 0.05 \\
\hline$\Delta \mathrm{LnK}_{\mathrm{t}}$ & $0.16^{* *}$ & 0.04 & 0.02 \\
\hline$\Delta \mathrm{LnK}_{\mathrm{t}-1}$ & $-0.10^{* *}$ & 0.04 & 0.03 \\
\hline $\mathrm{R}^{2}$ & \multicolumn{2}{|c|}{0.67} & \\
\hline \multicolumn{4}{|c|}{$\operatorname{Adj}-R^{2} 0.59$} \\
\hline \multicolumn{4}{|c|}{ Panel C: Diagnostic tests: } \\
\hline & Test & F-statistics & Probability value \\
\hline & $\chi^{2}$ Serial & 0.22 & 0.26 \\
\hline & $\chi^{2} \mathrm{ARCH}$ & 0.31 & 0.42 \\
\hline & $\chi^{2}$ White & 0.66 & 0.88 \\
\hline & $\chi^{2}$ Ramsey & 0.29 & 0.31 \\
\hline
\end{tabular}

Notes: (1) ${ }^{* * *, * * *}$ represent the significance at $1 \%, 5 \%$, and $10 \%$ levels, respectively.

(2) $\chi^{2}$ Serial is for serial correlation, $\chi^{2} \mathrm{ARCH}$ for autoregressive conditional heteroscedasticity, $\chi^{2}$ White for white heteroscedasticity, and $\chi^{2}$ Ramsey for Ramsey reset test. 


\section{Al Macrothink}

Source: The output of Micro-Fit econometric software package (version 5.1).

Table 6 also shows that $\Delta \mathrm{LnEC}_{\mathrm{t}}, \Delta \mathrm{LnFDI}_{\mathrm{t}}$, and $\Delta \mathrm{LnK}_{\mathrm{t}}$ are positively linked with the $\Delta \mathrm{LnGDP}_{\mathrm{t}}$ in the short-run. In contrast, the $\Delta \mathrm{LnFD}_{\mathrm{t}}$ and $\Delta \mathrm{LnK}_{\mathrm{t}-1}$ are negatively associated with the $\Delta \mathrm{LnGDP}_{\mathrm{t}}$. The results of diagnostic tests are detailed in Panel $\mathrm{C}$ of Table 6 . These results show that there is no evidence of serial autocorrelation and Heteroscedasticity.

\subsection{Impulse response function test}

Pesaran and Shin (1998) argued that the impulse response function (IRF) is a generalized forecast of error standard deviation to test the strength and credibility of causal relationship between variables. In fact, the VECM Granger causality test has a limitation. This test cannot capture the strength and credibility of causal relation between the variables. To solve this issue, however, we employed the IRF test. This test is based on the VAR model to display the reaction in one variable due to shocks stemming in other variables.Fig. 5 indicates a positive response in the GDP due to standard shocks stemming in the EC over the next 10 periods. The contribution of the FD in the GDP is positive but becomes negative after the second year. Both of the FDI and K contribute positively in the GDP but their contributions in the GDP become negatively after the next fifth year.

Response to Cholesky One S.D. Innovatios (+, -) 2 S.E.

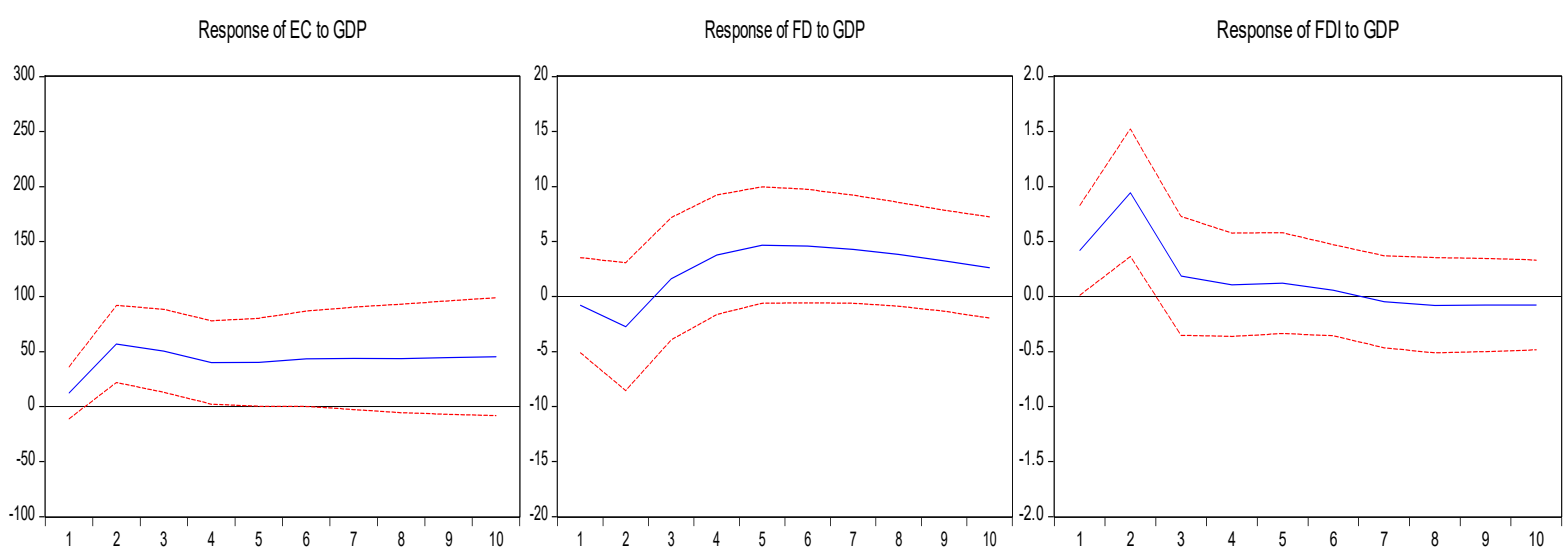

Response of K to GDP

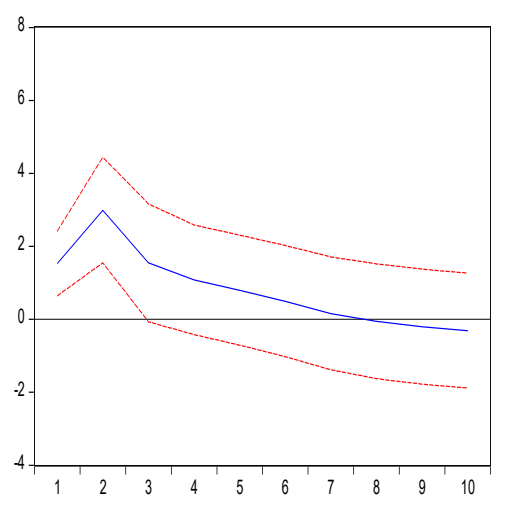

Figure 5. Impulse response function 
Source: The output of E-views econometric software package (version 8.1).

\section{Conclusions}

This paper re-analyses equilibrium relationships and causality directions among economic growth, energy consumption, financial development, foreign direct investment inflows, and gross fixed capital formation in Malaysia for the (1971-2013) period. The results of descriptive statistics tests show that variables have stable econometrics properties (i.e., (ct)s $\mathrm{N}\left(0, \sigma^{2}\right)$. The $H_{0}$ of Heteroscedasticity among variables has been rejected confirming the usage of VECM. The findings of KPSS test demonstrate that variables are stationary at I(1). The trace and maximal eigenvalues statistics tests display the existence of two co-integrating vectors among variables. However, the VECM results show long-run bidirectional Granger causality among variables as the coefficients of $\left(\mathrm{EET}_{\mathrm{t}-1}\right) \mathrm{s}$ are significant and in negative signs. Furthermore, a short-run unidirectional Granger causality has been detected from energy consumption to economic growth; financial development to energy consumption; gross fixed capital formation to financial development. The ARDL findings show that energy consumption, financial development, foreign direct investment inflows, and gross fixed capital formation boost economic growth in long-run.

\section{Policy implications and further study}

The mutual long-run bidirectional Granger causality among variables suggest the following notes:

a) The bidirectional Granger causality between economic growth and energy consumption suggest the existence of non-neutrality hypothesis. The Malaysian economy is highly dependent on the consumption of energy to achieve the desired economic growth rate, $7 \%$, by 2020 (Economic Transformation Policy Report, 2012).

b) The bidirectional Granger causality between economic growth and financial development implies the supply and leading hypotheses. The endogenous growth theory suggests that financial development is an important driver of economic growth through the allocation of resources, capital accumulation, and technological innovation (Bencivenga \& Bruce, 1991; Greenwood \& Jovanovic, 1990).

c) The bidirectional Granger causality between economic growth and foreign direct investment inflows indicates that foreign direct investment inflows would spur economic growth of the host country directly through the diffusion of technologies and accumulation of gross fixed capital formation. Also, the foreign direct investment inflows would promote economic growth indirectly through labour training and skills acquisition.

Therefore, the Malaysian government ought to continue implementing the national vision and economic transformation policies in order to spur economic growth. The emphasis on the total factor productivity strategy is necessary to boost high value activities in manufacturing, services, and agriculture sectors, which in turn improves the quality and quantity of output. 
The collaboration between private and public sectors is mandatory to establish more small and medium projects that ultimately attracts foreign investments and improves the output. The reduction of the dependence on the petroleum products through the usage of biofuel, biodiesel, and solar energy encourage the consumption of energy which is necessary to foster economic growth. However, a further research could be done to re-examine the determinants of economic growth by adding employment levels in economic sectors.

\section{References}

Abu-Bader, S., \& Abu-Qarn, A.S. (2008). Financial development and economic growth: The Egyptian experience. Journal of Policy Modeling, 30(5), 887-898. https://doi.org/10.1016/j.jpolmod.2007.02.001

Alam, M.J., Begum, I.A., Buysse, J., \&Huylenbroeck, G.V. (2012). Energy consumption, carbon emissions and economic growth nexus in Bangladesh: Co-integration and dynamic $\begin{array}{llll}\text { causality } \quad \text { analysis. } & \text { Energy 217-225. }\end{array}$ https://doi.org/10.1016/10.1016/j.enpol.2012.02.022

Alam, M.J., Begum, I.A., Buysse, J., Rahman, S., \&Huylenbroeck, G.V. (2011). Dynamic modeling of causal relationship between energy consumption, $\mathrm{CO}_{2}$ emissions and economic growth in India.Renewable and Sustainable Energy Reviews, 15(6), 3243-3251. https://doi.org/10.1016/j.rser.2011.04.029

Altinay, G., \&Karagol, E. (2004).Structural breaks, unit root, and the causality between energy consumption and GDP in Turkey. Energy Economics, 26(6), 985-994. https://doi.org/10.1016/j.eneco.2004.07.001

Al-Yousif, Y.K. (2002). Financial development and economic growth: Another look at the evidence from developing countries. Review of Financial Economics, 11(2), 131-150. https://doi.org/10.1016/S1058-3300(02)00039-3

Ang, J.B. (2008a). What are the mechanisms linking financial development and economic growth in Malaysia? Economic Modelling, 25(1), 38-53. https://doi.org/10.1016/j.econmod.2007.04.006

Ang, J.B. (2008b). Economic development, pollutant emissions and energy consumption in $\begin{array}{llll}\text { Malaysia.Journal of } \quad \text { Policy } \quad \text { Modelling, } & 30(2),\end{array}$ https://doi.org/10.1016/j.jpolmod.2007.04.010

Ang, J.B., \&Mckibbin, W.J. (2007). Financial liberalization, financial sector development and growth: Evidence from Malaysia. Journal of Development Economics, 84(1), 215-233. https://doi.org/10.1016/j.jdeveco.2006.11.006

Anwar, S., \& Sun, S. (2011). Financial development, foreign investment and economic growth in Malaysia.Journal of Asian Economics, 22(4), 335-342. https://doi.org/10.1016/j.asieco.2011.04.001 
Apergis, N., \& Payne, J.E. (2010). Renewable energy consumption and economic growth: Evidence from a panel of OECD countries. Energy Policy, 38(1), 656-660. https://doi.org/10.1016/j.enpol.2009.09.002

Asafu-Adjaye, J. (2000). The relationship between energy consumption, energy prices and economic growth: time series evidence from Asian developing countries. Energy Economics, 22(6), 615-625. https://doi.org/10.1016/S0140-9883(00)00050-5

Azlina, A.A., \& Mustapha, N.H.N. (2012). Energy, economic growth and pollutant emissions nexus: The case of Malaysia. Procedia-Social and Behavioral Sciences, 65(3), 1-7. https://doi.org/10.1016/j.sbspro.2012.11.082

Bekhet, H.A., \&Mugableh, M.I. (2012).Investigating equilibrium relationships between macroeconomic variables and Malaysian stock market index through bounds tests approach.International Journal of Economics and Finance, 4(10), 69-81. https://doi.org/10.5539/ijef.v4n10p69

Bekhet, H.A., \& Mugableh, M.I. (2013).Examining the equilibrium relationships between foreign direct investment inflows and employment in manufacturing and services sectors: evidence from Malaysia. Journal of Social and Development Sciences, 4(1), 32-38. https://www.researchgate.net/publication/253330028_Examining_the_Equilibrium_Relations hips_between_Foreign_Direct_Investment_Inflows_and_Employment_in_Manufacturing_an d_Services_Sectors_Evidence_from_Malaysia

Bekhet, H.A., \&Mugableh, M.I. (2016). Blueprinting the equilibrium relationships between inward FDI and employment in the Malaysian economic sectors: time series models approach. Global Business and Economics Review, 18(2), 136-150. https://doi.org/10.1504/GBER.2016.075507

Bekhet, H.A., \& Othman, N.S. (2011). Causality analysis among electricity consumption, consumer expenditure, gross domestic product (GDP) and foreign direct investment (FDI): Case study of Malaysia. Journal of Economics and International Finance, 3(4), 228-235. http://www.academicjournals.org/JEIF

Bekhet, H.A., \& Othman, N.S. (2018).The role of renewable energy to validate dynamic interaction between $\mathrm{CO}_{2}$ emissions and GDP toward sustainable development in Malaysia. Energy Economics, 72, 47-61. https://doi.org/10.1016/j.eneco.2018.03.028

Bekhet, H.A., \& Yasmin, T. (2013).Disclosing the relationship among CO2 emissions, energy consumption, economic growth and bilateral trade between Singapore and Malaysia: An econometric analysis. International Journal of Management Science and Engineering,7, 276-281.

https://www.researchgate.net/publication/310842648_Disclosing_the_relationship_among_C O2_emissions_energy_consumption_economic_growth_and_bilateral_trade_between_Singap ore_and_Malaysia_An_econometric_analysis

Belloumi, M. (2009). Energy consumption and GDP in Tunisia: Co-integration and causality analysis. Energy Policy, 37(7), 2745-2753. https://doi.org/10.1016/j.enpol.2009.03.027 
Bencivenga, V.R., \& Bruce, D.S. (1991).Financial intermediation and endogenous growth. The Review of Economic Studies, 58(2), 195-209. http://www.jstor.org/stable/2297964

Bojanic, A.N. (2012). The impact of financial development and trade on the economic growth of Bolivia. Journal of Applied Economics, 15(1), 51-70. https://doi.org/10.1016/S1514-0326(12)60003-8

Boutabba, M.A. (2014). The impact of financial development, income, energy and trade on carbon emissions: Evidence from the Indian economy. Economic Modelling, 40, 33-41. https://doi.org/10.1016/j.econmod.2014.03.005

Brooks, C. (2008). Introductory econometrics for finance ( $1^{\text {st }}$ ed.)', Cambridge University Press Publisher, USA: New York.

Calderon, C., \& Liu, L. (2003). The direction of causality between financial development and economic growth. Journal of Development Economics, 72(1), 321-334. https://doi.org/10.1016/S0304-3878(03)00079-8

Campos, N.F., Karanasos, M.G., \& Tan, B. (2012). Two to tangle: Financial development, political instability and economic growth in Argentina. Journal of Banking \& Finance, 36(1), 290-304. https://doi.org/10.1016/j.jbankfin.2011.07.011

Chang, T. (2002). Financial development and economic growth in mainland China: a note on testing demand following or supply leading hypothesis. Applied Economic Letters, 9(13), 869-873. https://doi.org/10.1080/13504850210158962

Christopoulos, D.K., \& Tsionas, E.G. (2003). Financial development and economic growth: evidence from panel unit root and co-integration tests. Journal of Development Economics, 73(1), 55-74. https://doi.org/10.1016/j.jdeveco.2003.03.002

Dagher, L., \& Yacoubian, T. (2012).The causal relationship between energy consumption and economic growth in Lebanon. Energy Policy, 50, 795-801. https://doi.org/10.1016/j.enpol.2012.08.034

Deb, S.G., \& Mukherjee, J. (2008). Does stock market development cause economic growth? A time series analysis for Indian economy. International Research Journal of Finance and Economics, 21 , 142-149. https://www.researchgate.net/publication/254945009_Does_Stock_Market_Development_Ca use_Economic_Growth_A_Time_Series_Analysis_for_Indian_Economy

Durbin, J., \& Watson, G.S. (1950). Testing for serial correlation in least squares regression. Biometrika, 38, 409-428. http://www.jstor.org/stable/2332325

Economic Transformation Policy Report (2012). Economic transformation report towards the Malaysian 2020 vision. Available on line at: http://etp.pemandu.gov.my/annualreport/upload/Eng_ETP2012_01_Opening.pdf 
Engle, R.F. (1982). Autoregressive conditional Heteroscedasticity with estimates of the variance of United Kingdom inflation. Econometrica, 50(4), 987-1007. http://www.jstor.org/stable/1912773

Engle, R.F., \& Granger, C.W.J. (1987). Co-integration and error correction: Representation estimation and testing. Econometrica, 55(2), 251-276. http://www.jstor.org/stable/1913236

Greenwood, J., \& Jovanovic, B. (1990).Financial development, growth, and the distribution of income. Journal of Political Economics, 98(5), 1076-1107. http://www.nber.org/papers/w3189

Gujarati, D., \& Porter, D. (2009).Basic Econometrics (5 ${ }^{\text {th }}$ ed.)', McGraw-Hill Publishing Companies, Inc. USA: New York.

Hamdi, H., Sbia, R., \& Shahbaz, M. (2014). The nexus between electricity consumption and economic growth in Bahrain. Economic Modelling, 38, 227-237. https://doi.org/10.1016/j.econmod.2013.12.012

Harris, R.I.D. (1995). Using co-integration analysis in econometric modeling ( $1^{\text {st }}$ ed.)', A Pearson Education Company Publisher. England: London.

Hassan, M.K., Sanchez, B., \& Yu, J-S. (2011). Financial development and economic growth: New evidence from panel data. The Quarterly Review of Economics and Finance, 51(1), 88-104. https://doi.org/10.1016/j.qref.2010.09.001

Hondroyiannis, G., Lolos, S., \& Papapetrou, E. (2005). Financial markets and economic growth in Greece, 1986-1999.Journal of International Financial Markets, Institutions \& Money,15(2), 173-188. https://doi.org/10.1016/j.intfin.2004.03.006

Hsueh, S-J., Hu, Y-H., \& Tu, C-H. (2013). Economic growth and financial development in Asian countries: A bootstrap Granger causality analysis. Economic Modelling,32, 294-301. https://doi.org/10.1016/j.econmod.2013.02.027

Islam, F., Shahbaz, M., Ahmed, A.U., \&Alam, M. M. (2013). Financial development and energy consumption nexus in Malaysia: A multivariate time series analysis. Economic Modelling,30, 435-441. https://doi.org/10.1016/j.econmod.2012.09.033

Jarque, C.M., \& Berra, A.K. (1980). Efficient tests for normality, homoscedasticity, and serial independence of regression residuals. Economic Letters,6(3), 255-259. https://doi.org/10.1016/0165-1765(80)90024-5

Jobert, T., \& Karanfil, F. (2007). Sectoral energy consumption by source and economic $\begin{array}{llll}\text { growth in } \quad \text { Turkey.Energy } & \text { Policy, }\end{array}$ https://doi.org/10.1016/j.enpol.2007.05.008

Johansen, S., \& Juselius, K. (1990).Maximum likelihood estimation and inference on co-integration-with applications to the demand for money. Oxford Bulletin of Economics and Statistics, 52(2), 169-210. https://doi.org/10.1111/j.1468-0084.1990.mp52002003.x 
Kar, M., Nazlioglu, S., \& Agir, H. (2011). Financial development and economic growth nexus in the MENA countries: Bootstrap panel granger causality analysis. Economic Modelling,28, 685-693. https://doi.org/10.1016/j.econmod.2010.05.015

Kwiatkowski, D., Phillips, P.C.B., Schmidt, P., \& Shin, Y. (1992).Testing the null hypothesis of stationary against the alternative of a unit root. Journal of Econometrics, 54, 159-178. https://doi.org/10.1016/0304-4076(92)90104-Y

Lean, H.H., \& Smyth, R. (2010). $\mathrm{CO}_{2}$ emissions, electricity consumption and output in ASEAN. Applied Energy, 87(6), 1858-1864.https://doi.org/10.1016/j.apenergy.2010.02.003

Liang, Q., \&Teng, J-Z. (2006). Financial development and economic growth: Evidence from China. China Economic Review, 17(4), 395-411. https://doi.org/10.1016/j.chieco.2005.09.003

Liu, W-C., \& Hsu, C-M. (2006). The role of financial development in economic growth: The experiences of Taiwan, Korea, and Japan. Journal of Asian Economics, 17(4), 667-690. https://doi.org/10.1016/j.asieco.2006.06.007

Mackinnon, J.G., Haug, A.A., \&Michelis, L. (1999). Numerical distribution functions of likelihood ratio tests for co-integration. Journal of Applied Econometrics, 14(5), 563-577. https://doi.org/10.1002/(SICI)1099-1255(199909/10)14:5<563::AID-JAE530>3.0.CO;2-R

Menyah, K., \& Wolde-Rufael, Y. (2010).Energy consumption, pollutant emissions and economic growth in South Africa. Energy Economics, 32(6), 1374-1382. https://doi.org/10.1016/j.eneco.2010.08.002

Mugableh, M.I. (2013). Analysing the $\mathrm{CO}_{2}$ emissions function in Malaysia: Autoregressive distributed lag approach. Procedia Economics and Finance, 5, 571-580. https://doi.org/10.1016/S2212-5671(13)00067-1

Mugableh, M.I. (2015a). Economic growth, $\mathrm{CO}_{2}$ emissions, and financial development in Jordan: Equilibrium and dynamic causality analysis. International Journal of Economics and Finance, 7(7), 98-105. https://doi.org/10.5539/ijef.v7n7p98

Mugableh, M.I. (2015b). Time series analysis of inward foreign direct investment function in Malaysia. Procedia - Social and Behavioral Sciences, 172, 679-685. https://doi.org/10.1016/j.sbspro.2015.01.419

Mugableh, M.I. (2015c). Equilibrium models of the Malaysian stock market and macro economy ( $1^{\text {st }}$ ed), LAP LAMBERT Academic Publishing. Germany: Berlin. ISBN: 978-3-659-78870-3

Mugableh, M.I. (2017a). World oil price volatility and stock returns fluctuations: evidence from Southeast Asian equity markets. Science International, 29(4), 759-762. https://www.researchgate.net/publication/318897616_WORLD_OIL_PRICE_VOLATILITY _AND_STOCK_RETURNS_FLUCTUATIONS_EVIDENCE_FROM_SOUTHEAST_ASIA N_EQUITY_MARKETS 
Mugableh, M.I. (2017b). Estimating elasticity function of Jordanian aggregate import demand. Applied Economics and Finance, 4(2), 33-37. https://doi.org/10.11114/aef.v4i2.2085

Narayan, P.K. (2005). The saving and investment nexus for China: evidence from co-integration tests. Applied Economics, 37(17), 1979-1990. https://doi.org/10.1080/00036840500278103

Ozturk, I., \& Acaravci, A. (2010). $\mathrm{CO}_{2}$ emissions, energy consumption and economic growth in Turkey. Renewable and Sustainable Energy Reviews, 14(9), 3220-3225. https://doi.org/10.1016/j.rser.2010.07.005

Patrick, H.T. (1966). Financial development and economic growth in underdeveloped countries. Economic Development and Cultural Change, 14(2), 174-187. http://www.jstor.org/stable/1152568

Pesaran, M.H., Shin, Y., \& Smith, R.J. (2001). Bounds testing approach to the analysis of level relationships. Journal of Applied Econometrics, 16(3), 289-326. https://doi.org/10.1002/jae.616

Shahbaz, M., Solarin, S.A., Mahmood, H., \& Arouri, M. (2013). Does financial development reduce $\mathrm{CO}_{2}$ emissions in Malaysian economy? A time series analysis. Economic Modelling, 35, 145-152. https://doi.org/10.1016/j.econmod.2013.06.037

Shan.J., \& Jianhong, A. (2006). Does financial development lead economic growth? The case of China. Annals of Economics and Finance, 7(1), 231-250. https://ideas.repec.org/a/cuf/journl/y2006v7i1p197-216.html

United Nations Development Programme Report (2006). Achieving industrial energy efficiency in Malaysia', Available on line at: http://www.undp.org.my/uploads/achieving_industrial_energy_efficiency_2006.pdf

Wang, S.S., Zhou, D.Q., Zhou, P., \& Wang, Q.W. (2011). $\mathrm{CO}_{2}$ emissions, energy consumption and economic growth in China: A panel data analysis. Energy Policy, 39(9), 4870-4875.https://doi.org/10.1016/j.enpol.2011.06.032

Yang, Y.Y., \& Yi, M.H. (2008). Does financial development cause economic growth? Implication for policy in Korea. Journal of Policy Modeling, 30(5), 827-840. https://doi.org/10.1016/j.jpolmod.2007.09.006

Zhang, J., Wang, L., \& Wang, S. (2012). Financial development and economic growth: Recent evidence from China. Journal of Comparative Economics, 40(3), 393-412. https://doi.org/10.1016/j.jce.2012.01.001

Zhang, X.P., \& Cheng, X.M. (2009).Energy consumption, carbon emissions, and economic growth in China. Ecological Economics, 68(10), 2706-2712. https://doi.org/10.1016/j.ecolecon.2009.05.011 